ISSN: 2655-6251

\title{
Zakat Based on Programs' Tender: Effectiveness of Productive Zakat Fundraising in Indonesia
}

\author{
Sulistyowati \\ STIE Indonesia Banking School \\ Paper to be presented at International Conference of Zakat 2018 \\ 15-16 November, Universitas Gadjah Mada, Yogyakarta, Indonesia
}

\section{ABSTRACT}

The study aims to identify and explore deeply the effectiveness of productive zakat mobilization at Dompet Dhuafa as success zakat fundriser by tendering innovative, creative and interesting four grand programs consist of healthcare; education; enterprenuership for poor; and social development aspects. The study is qualitatative research using primary data through unstructured interview with Dompet Dhuafa. Secondary data was collected from National Zakat Board (BAZNAS) and Islamic Relief Foundation as benchmark institutions.

The first result indicates significant benefit of productive zakat implication both in BAZNAS and Dompet Dhuafa. Productive zakat plays the important role it is eradicating poverty and increasing prosperity index in 28 provinces in 2017 and also ensuring sustainable economic empowerement of the poor. Second results demonstrated the strong influence strategy of productive zakat fundraising. In this case, zakat collection by tender or auctioning program. This is Dompet Dhuafa's creative and extraordinary approaches which is not many philanthropic organization in Indonesia used it. It is kind of modern and innovative method of fundraising which need proffesional improvement for next bigger success. According to this, Islamic Relief Foundation UK, becomes great role model for developing fundraising strategy at international level.The limitation of this research might not be able to represent the condition all over the years in Indonesia, so advanced research is needed based on each specific aspect from four big grand programs of Dompet Dhuafa to enhance detail trend by different perspectives.

Keywords_Productive zakat, Fundraising effectiveness, Muzakki, Poverty

\section{INTRODUCTION}

The last view years, Indonesia shows the seriousness on developing Islamic philanthropy, one of them by increasing the role of productive zakat. As one of the five pillars in Islam, the significance of zakat is largely attributed to its effectiveness as a distribution tool in the process of wealth circulation and social security (Akmar et al, 2017). Zakat is a part of the economic elements in Islam and it has an important role in the Indonesian economy (Beik, 2017).
Indonesia is a country with the biggest Muslim population in the world. It causes the zakat potential are huge with significant growth each year. National zakat growth throughout 2017 increased by around 20\% from the previous year to 6 trillion rupiahs, which was compiled by the National Zakat Board (BAZNAS) and the Amil Zakat Institution (LAZ) (Nasar, 2018). Along with the increase in zakat payment services that are increasingly creative and innovative, including through digital services, it turns out that the realization can reach $30 \%$ of the total zakat receipts. Based on the BAZNAS 
survey, the potential for zakat maal and individual income in Indonesia can actually reach 138 trillion rupiahs per year (BAZNAS, 2018).

Discuss about zakat potential is not separated from the beneficiaries in this case is number of poor people in Indonesia and real number of zakat fund collected as follows.

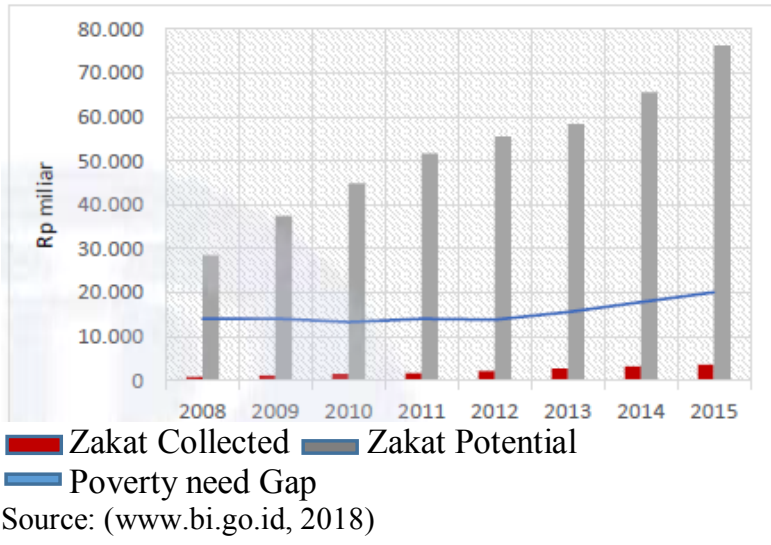

Figure 1. Poverty data, Statistics Central Beurau (BPS); Zakat Collection, data BAZNAS

Based on Figure 1, there was significant gap among poverty index, zakat potential and real zakat collected. Currently, zakat fund is still far from the target. Meanwhile the need of poverty gap as far as on chart shown. It is big work for Indonesia to solve the significant gap as mentioned.

Dompet Dhuafa committed to targeting the zakat growth, infaq, shodaqoh and waqf (ZISWAF) collection. It proven by the donation increase who distributed their Ziswaf through Dompet Dhuafa in 2016. Still in the same year, Dompet Dhuafa also spreads more empowerment for beneficiaries. Indeed, still in the same period, the benefeciaries from rolling empowerment program riched 1.832 .066 people or increasing 21,33 percent than previous period (Taufan, 2017). The succes of Dompet Dhuafa.

The data explained above proves that Dompet Dhuafa is one of an outstanding Islamic philanthropic oragnization in Indonesia which is good to be a main role model particularly in fundraising strategic aspect. This is in accordance with Anwar (2017) expression tha the purpose of zakat is to develop socio-economic value, and it will be hard to be achieved if there is no active and creative role from the amil whom is expected to be professional and innovative in organizing the zakat funds (Anwar, 2017).

Regarding zakat fundraising strategies, one of them is conducting program auction events to potential donors, where such fundraising strategies have not been widely implemented by other philanthropic institutions. So, based on the background, the study aims to identify, to explore and to analyse the effectiveness of fundraising strategy by tendering its programs to collect productive zakat in Dompet Dhuafa organization as success zakat fundriser.

\section{LITERATURE REVIEW}

Zakat, as a tool for economic empowerment which can play a significant role in both Islamic commercial and social finance. The Qur'an mentions the Word zakat 30 times and three places it appear as being commanded by God. Zakat is often called Sadaqah in the Qur'an. The importance of zakat as an obligation on Muslim is also emphasized in many sayings of the prophet (pbuh) (Ahmed, 2004). According to the some sayings, zakat is recognized as one of the five pillars in Islam.

During the Ottoman Empire, zakat evolved together with philanthropic activities, such as the waqf system. Motivated by piety, Muslims organized the waqf under the auspices of shari'a and society. Even though the Qur'an does not require waqf, several verses in the holy text advise the faithful to be charitable over and above the requirement to pay zakat (Lessy, 2013). According to the puposes, zakat devided into 
several types, one of them is productive zakat. It is classified as contemporary zakat.

Anwar (2017) emphasize from his research that zakat Empowerment should have a positive impact on mustahiq, both economically and socially. From the economic side, mustahiq are demanded to have independen and worthy life. In terms of social, mustahiq are required to live in equal with the other communities. It means, zakat is not only distributed to something consumptive, but rather to the benefit of productive and educative. Zakat productive must be able to train mustahiq, so that s(he) is ready to change.

Zakat which can be assembled in the long-term should be able to empower mustahiq reached the stage of business development. Consumptive zakat only plays short periode, while the empowerment program should take as the priority one. The general meaning of empowerment is creating independent partners, so that the partners (mustahiq) are not always depend on the amil (Ridwan, 2005)

Currently, many zakat organizations attempted to encourage productive zakat program for empowering the poor as poverty eradication effort in Indonesia. Certainly, the productive programs could be realized after the basic needs of the recipients have been fully met. Generally, the method of the programs are by introducing or supporting the economic activities for the poor. The capital given is just kind of charity. They do not need to repay that money since zakat is considered as their own right. Furthermore, the category insists that the productive should be prioritized in delivering zakat because it can educate the poor to use the money effectively (Sudirman, 2016).

Discuss about productive zakat cannot be separated from the discourse on fundraising strategies of it. CRA (2012) defined fundraising as "any activity that includes a solicitation of present or future donations of cash or gifts in kind, or services to raise funds, whether explicit or implicit". Moreover Holloway (2001) in Sulthoni (2017) classifies fundraising into three categories. Firstly, raising moveable and immovaable resources from society. Secondly, creating a base of revenues from the existing assets by investment and innovations. Thirdly, utilising non-monetary resources such as volunteers, equipment and positive images of the institutions to achieve the resources.

This study refers to previous research about how to collect productive zakat by effective fundraising. Strategy fundraising usually adopt market-oriented approaches to transform episodic and irregular donors into long term regular members and donors. Alternatively, the zakat institutions might utilise zakat with the aim of increasing the zakat future benefits through investment (Sulthoni et al, 2018) in this case, productive zakat.

One of the zakat collection methods which is part of Partnership Fundraising Approach is by auctioning or tendering Dompet Dhuafa's programs. Specifically Carpenter et al. (2007) describes that auctions are a popular way to raise money for charities, but relatively little is known, either theoretically or empirically, about the properties of charity auctions. The small theoretical literature suggests that the all-pay auction should garner more money than winner-pay auctions.

\section{METHODOLOGY}

This research was conducted in Dompet Dhuafa Jakarta and National Zakat Board (BAZNAS). The institutions were choosed because represent a success zakat fundriser in Indonesia. Researcher analyses the strategy of zakat fundraising by auction or tendering 
an innovative, creative and interesting program.

To achieve the objectives of the study, the researcher primarily used interviews as the main source of data. Along with interviews, collecting secondary data from BAZNAS and various sources on the same issue, it can improve the validity of the findings otherwise known as contextual validity in case studies (Scapens, 1990). Multiple sources of data enabled the researcher to triangulate the data which consequently helps to gain from multiple sources of information (Shank, 2002).

\section{RESULTS AND DISCUSSION}

Irfan Syauki Beik (2009) emphasizes the analysis of the role of zakat in reducing poverty which was conducted at Dompet Dhuafa. The result shows that zakat was able to reduce the number of poor families from $84 \%$ to $74 \%$. Whereas from the aspect of the depth of poverty, zakat also proved able to reduce the poverty and income gap, which was indicated by a decrease from 540,657 Rupiahs to 410,337 Rupiahs and shows value from 0.43 to 0.33 . With the decline in the index value, then proving the zakat instrument has tremendous potential.

As Anis and Kassim (2016) underlines in their research finding that shed light on the effectiveness of zakat-based approach in alleviating poverty and ensuring sustainable economic empowerment. Herewith the comparison of BAZNAS Prosperity Index (BPI) among the 28 provinces in 2017. BPI in aggregate shows that the highest BPI is 0.85 and has been achieved by five provinces which are East Nusa Tenggara (NTT), North Kalimantan, South Kalimantan, West Papua and Bengkulu province. On the other hand, provinces that have the lowest BPI are Bangka Belitung and Gorontalo with value of 0.35 and 0.40 respectively it can be seen in table 3 below:

Table 1. BAZNAS Prosperity Index/BPI (2017)

\begin{tabular}{clcccc}
\hline No & \multicolumn{1}{c}{ Province } & $\begin{array}{c}\text { CIBEST } \\
\text { Prosperity } \\
\text { Index }\end{array}$ & $\begin{array}{c}\text { Modified HDI } \\
\text { Index }\end{array}$ & $\begin{array}{c}\text { Autonomy / } \\
\text { Independence } \\
\text { Index }\end{array}$ & $\begin{array}{c}\text { BAZNAS } \\
\text { Prosperity } \\
\text { Index }\end{array}$ \\
\hline 1 & Bengkulu & 1 & 0.75 & 0.75 & 0.85 \\
2 & West Kalimantan & 0.5 & 0.75 & 0.75 & 0.65 \\
3 & West Papua & 1 & 0.75 & 0.75 & 0.85 \\
4 & Riau & 1 & 0.75 & 0.5 & 0.8 \\
5 & West Sulawesi & 0.75 & 0.75 & 0.5 & 0.7 \\
6 & West Sumatera & 1 & 0.75 & 0.5 & 0.8 \\
7 & South Sumatera & 0.75 & 0.75 & 75 & 0.75 \\
8 & Bali & 0.75 & 0.75 & 0.5 & 0.7 \\
9 & East Java & 0.75 & 0.75 & 0.75 & 0.75 \\
10 & West Nusa Tenggara & 0.75 & 0.75 & 0.75 & 0.75 \\
11 & Gorontalo & 0 & 0.75 & 0.5 & 0.4 \\
12 & Bangka Belitung & 0 & 0.75 & 0.25 & 0.35 \\
13 & West Java & 1 & 0.75 & 0.5 & 0.8 \\
14 & Jambi & 1 & 0.75 & 0.5 & 0.8 \\
15 & South Kalimantan & 1 & 0.75 & 0.75 & 0.85 \\
16 & North Kalimantan & 1 & 0.75 & 0.75 & 0.85 \\
17 & Central Kalimantan & 0.75 & 0.75 & 0.5 & 0.7 \\
18 & East Kalimantan & 0.75 & 0.75 & 0.5 & 0.7 \\
19 & Riau Island & 0.75 & 0.75 & 0.5 & 0.7
\end{tabular}




\begin{tabular}{llcccc}
20 & Central Sulawesi & 0.75 & 0.75 & 0.5 & 0.7 \\
21 & North Sumatera & 0.5 & 0.75 & 0.5 & 0.6 \\
22 & Sulawesi Tenggara & 0.75 & 0.75 & 0.5 & 0.7 \\
23 & Central Java & 1 & 0.25 & 0.75 & 0.65 \\
24 & D.I Yogyakarta & 1 & 0.5 & 0.75 & 0.75 \\
25 & Banten & 0.75 & 0.5 & 0.75 & 0.6 \\
26 & East Nusa Tenggara & 1 & 0.75 & 0.5 & 0.85 \\
27 & North Sulawesi & 1 & 0.75 & 0.5 & 0.63 \\
28 & Aceh & 0.75 & 0.75 & 0.5 & 0.62 \\
\hline & Average Value & $\mathbf{0 . 7 9}$ & $\mathbf{0 . 7 1}$ & $\mathbf{0 . 5 9}$ & $\mathbf{0 . 7 1}$ \\
\hline
\end{tabular}

Source: BAZNAS (2017)

According to table 1, the average value of the BAZNAS Prosperity Index is 0.71 (Good) which means the productive zakat program in 28 provinces has a positive impact. the average value of both the CIBEST Prosperity Index and the Modified HDI Index are categorized as Good while the average value of the Autonomy/ Independence Index is the lowest compared to the other indexes. It means that the productive zakat program by BAZNAS needs to be enhanced in order to achieve a sustainable impact on the autonomy/independence aspect of the mustahik. In addition, the program needs to be redesigned to have a scheme or exit strategy thus the mustahik do not back to their poor economic condition after the program ends.

In addition, based on data above that shows the necessarily to improve innovative productive zakat programs describes by BAZNAS, Dompet Dhuafa continues to increase its role in improving the economic and social welfare of the community through productive zakat by trying to improve trust from the public as well. Such Ali et al (2017) finding indicates that participation on paying zakat through zakat institution is not only affected by payer attitude but also their trust toward institution to handle the zakat fund collected properly and also their degree of understanding about zakat The implication is that the effort that implemented by various party which is form government and also person close with the payer. The result from this study might contribute to the improvement by zakat institution for better system to help the poor and need.

Dompet Dhuafa proved an effort for many years related to zakat fundraising program and as we know, as figure below it is the most trusted and popular zakat institutions in Indonesia.

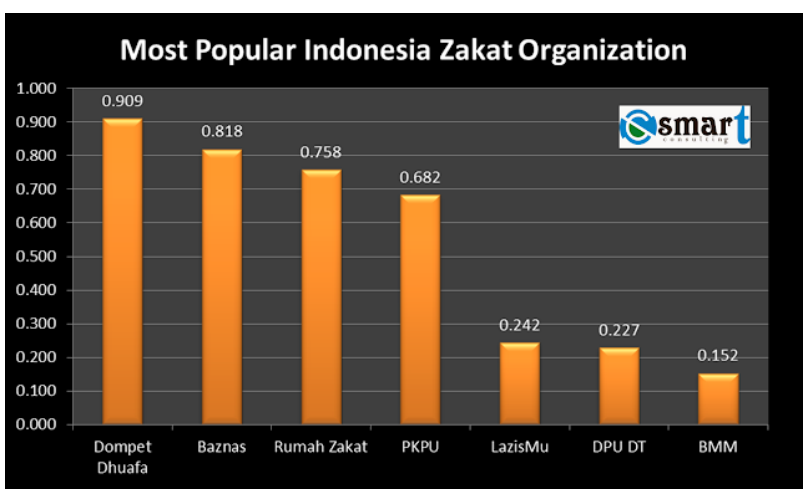

Source: SMART Consulting, 2016

Figure 2. Most Popular Indonesia Zakat Organization (World Giving Index)

Based on figure 1, SMART Consulting captures the popularity level of zakat management institutions as part of brand awareness of zakat in Indonesia. The study was conducted through a survey of 132 selected respondents related to zakat management organizations both public and private. The result shows, $90.9 \%$ recognize Dompet Dhuafa as populer institution. Furthermore, BAZNAS is recognize by 
$81.8 \%$. The level of popularity of the Zakat House is $75.8 \%$, meanwhile PKPU is $68.2 \%$. These four OPZs are included in the cluster of Zakat institutions with relatively high popularity (Rusydiana, 2016).

\section{Description of Dompet Dhuafa Organization}

Dompet Dhuafa is a humanitarian NGO and a Lembaga Amil Zakat (LAZ)_a national organization that has been recognized by the state. It collects funding from the Muslims community, specifically from the ZISWAF (Zakat, Infaq, Alms and Wakaf) community which is channeled to the dhuafa people or the needy.

Dompet Dhuafa is a unique NGO that not only receives funding but also provides funding for beneficiaries in accordance with the provisions of Muslims. As Islamic rule, zakat fund for eight beneficiaries ( 8 asnaf) that also running a social enterprise which attracts investors. The profits from these investment will of course, return to the dhuafa community (Annur, 2018).

\section{Poverty Reduction Program of Dompet Dhuafa Organization}

To carry out the roles to reduce poverty number, DD performs four main activities, namely health, education, economic empowerment and social development.

Table 2. Poverty Reduction Program of Dompet Dhuafa Organization

\begin{tabular}{ll}
\hline \multicolumn{1}{c}{ Program } & \multicolumn{1}{c}{ Description } \\
\hline Health & $\begin{array}{l}\text { Through the free health care } \\
\text { services, Dompet Dhuafa runs } \\
\text { various curative, preventive } \\
\text { and promotive health } \\
\text { programs. Dompet Dhuafa set } \\
\text { up a free hospital for the poor } \\
\text { in } 2009 \text { in Bogor, Indonesia on } \\
\text { an area of more than 7.6 } \\
\text { hectares. The Integrated Health } \\
\text { House of Dompet Dhuafa }\end{array}$ \\
\hline
\end{tabular}

(Rumah Sehat Terpadu Dompet Dhuafa, RST DD) has complete facilities: polyclinics, specialist physicians, operating rooms, intensive care unit (ICU) and pharmacy under a complementary medical system. Dompet Dhuafa also runs eight clinics, twelve Gerai Sehat (sub-clinics) and fourtyfour Pos Sehat (health centers) throughout Indonesia.

Education The foundation has established several networks of schools and scholarships for poor children. These provide quality education at par with wellknown and established schools in Indonesia. Dompet Dhuafa continues to provide scholarships to 5,529 students. It has organized trainings for teachers who will be assigned to schools that are lagging behind in Indonesia. Dompet Dhuafa has trained 2,710 teachers who now teach at various schools throughout the country.

Economy Dompet Dhuafa formed an economic division to help the poor through various programs that will help them to become self-reliant. DD's economic program is now spread all over Indonesia.

Livestock Farming: Kampoeng Ternak is one of Dompet Dhuafa's programs, which has run various empowerment programs for fourteen years. Since its establishment in 2002, a total of 13,637 families have received donations in the form of livestock where 18,699 goats and sheep, and 777 cows have been donated under this program;

Agriculture Farming: Lembaga Pertanian Sehat (LPS) was found in 1999 to become center 


for research and development
of agriculture. This program
has helped many farmers in
developing sound agricultural
practices in various regions in
Indonesia. The program has
12,404 farmers or beneficiaries
until the end of 2015;
Small Business: Since 2000,
Dompet Dhuafa has helped
small-business in rural and
urban areas and even post-
disaster regions spread
throughout Indonesia through
economic empowerment
programs that may address
various social issues. The
number of beneficiaries of this
program has reached 15,620 by
the end of 2015.
One of the relief programs of
Dompet Dhuafa is to help
Indonesian migrant workers
living abroad. It is one of four
anti-poverty programs that
aimed to provide immediate
assistance to those in need,
serving their pragmatic needs
and offering them the quick and
effective ways to get out of
serious problems. The social
development programs of
Dompet Dhuafa also include
support for disaster victims and
migrant workers, legal aid for
the poor, and support for
environmental activities.

Source: Interviews and Dompet Dhuafa documents based on Ramon Magsaysay Award Foundation (2016)

Through various empowerment
programs conducted by DD to
overcome poverty, more than 13 million
people have become beneficiaries of Dompet
Dhuafa's programs. These programs have
helped to reduce the level of poverty severity
of the beneficiaries by 40 percent.

Through various empowerment overcome poverty, more than 13 million people have become beneficiaries of Dompet Dhuafa's programs. These programs have of the beneficiaries by 40 percent.
The Success of Dompet Dhuafa fundraising: Mobilization of Funds and Resources

To be able to mobilize funds and resources from the community. With a variety of campaign and fund raising programs, DD has managed to collect a total donation of US $\$ 20.2$

million IDR265,900,685,279 billion) in 2015. Dompet Dhuafa conducts a series of activities as follows (Interviews and Ramon, 2016):

a. Fundraising Program

1. Release interesting thematic publications on Zakat, infaq and waqf in various media.

2. Partner with companies and formulate a donation program through their finance department.

3. Open donation counters at places frequented by many people

4. Cooperate with various banks to provide easy access to make donations

5. Offer CSR programs to companies 6 . Offer donations pick-up service

b. Effective Communication and Publication

1. Issue the Swara Cinta (Voice of Love) magazine - a monthly magazine of 20,000 copies for donors.

2. Zakat Application on smart phones (iPad, iPhone, and iPod)

3. Zakat TV, a streaming television program

4. Launch the e-Zakat application, an Android-based platform

5. Manage the social media accounts (Facebook, Twitter, Instagram)

6. Manage the community radio station "Swara Cinta"

7. Place ads in various mass media

8. Work with online shopping sites (bukalapak.com, elevenia.com and others)

9. Organize the crowd funding in cooperation with kitabisa.com 
The Dompet Dhuafa's Zakat Fundraising through Program's Tender (Program's Auction)

Methods of Fundraising
The model of fundraising implemented in philanthropic organisation such as retail fundraising approach or partnership fundraising approach determines the success of fund collected. Sulthoni et al (2018) describes the methods of Zakat payment in retail approach below:

Table 3. Methods of Zakat Payment in Retail Approach

\begin{tabular}{|c|c|c|c|}
\hline \multicolumn{4}{|c|}{ Methods of Zakat Payments } \\
\hline Direct Payments & Implemented by & Indirect Payments & Implemented by \\
\hline $\begin{array}{l}\text { Cash payment at service } \\
\text { counter (in Zakat offices) }\end{array}$ & All organizations & $\begin{array}{c}\text { Regular direct debit } \\
\text { payment (from payroll or } \\
\text { bank deposit) }\end{array}$ & $\mathrm{G} 1, \mathrm{C} 1, \mathrm{C} 2$ \\
\hline $\begin{array}{l}\text { Cash payment through Zakat } \\
\text { services counter in public } \\
\text { places (mall, offices complex, } \\
\text { etc) }\end{array}$ & $\mathrm{G} 2, \mathrm{P} 1, \mathrm{P} 2$ & $\begin{array}{c}\text { Transfer through bank (via } \\
\text { bank counter, ATM, mobile } \\
\text { banking or internet } \\
\text { banking) }\end{array}$ & All organizations \\
\hline $\begin{array}{c}\text { Cash payment through pick-up } \\
\text { service }\end{array}$ & $\mathrm{G} 2, \mathrm{P} 1$ & $\begin{array}{l}\text { Transfer through point of } \\
\text { payments (via post office, } \\
\text { etc) }\end{array}$ & P1 \\
\hline
\end{tabular}

Source: (Sulthoni et al, 2018)

Based on table 3. Special for zakat payment in retail approach, there are many ways implemented by Islamic philanthropic organization that common use in Indonesia. As mentioned, Dompet Dhuafa also using this methods to mobilize zakat fund known as traditional or regular approach. According to the specific topic that choose. In this study the researcher focus on method of zakat partnership approach which is associated with special fundraising event/programs as describe below:

Table 4. Methods of Zakat Payment in Partnership Approach

\begin{tabular}{ll}
\hline Subtheme & Partnership Fundraising Approach \\
\hline Interview with & Remark (listed) \\
R1 (G1-1), R3 (G2-1) & Establishing partnership with institutional muzakki/donors. \\
& Particularly government and government-related institutions. \\
R14 (P1-1), R21 (P2-1) & Establishing partnership with institutional muzakki/donors. \\
& Particularly corporations and communities. \\
\hline R14 (P1-1), R21 (P2-1) & Often associated with special fundraising event/programs \\
\hline
\end{tabular}

Source: (Sulthoni et al, 2018)

Special fundraising event by programs auction and/ tendering event is one of smart and good contemporary way to collect zakat. As Gasca (2015) express the sevent essential tips for an effective fundraising strategy they are Set the expectations; Refine the value proposition;
Understand the internal rate of return (IRR); Formalize and train the team; Know the audience; Manage the strategy; and Get creative. Anyone who runs a non-profit organization understands the immense challenge with raising social-fund. With the right planning, training, team and 
expectations, your organization can more effectively raise the funds needed to create sustainability and make a long-term positive impact.

\section{The Story of Program's Tender (Fundraising} by auction) at Dompet Dhuafa

On October 17th 2015, Dompet Dhuafa organized fundraising event entitled "Voice of Children: Listen with Love". Join event between Dompet Dhuafa and United Nations High Commissioner for Refugees (UNHCR) holded two years ago became successful donation program.The donations collected be channeled to help children in Indonesia, including Rohingya refugee children. Furthermore, Voice of Children fundraising concert mobilized to support for Dompet Dhuafa, a leading humanitarian and non-profit organization in Indonesia that continues to help 38 million Indonesian children who do not have a birth certificate is 46 percent of the total all children in Indonesia.

The event shows the great reputation of Dompet Dhuafa because UNHCR felt honors became partner in this kind of charity. By proper synergy of every element such as TV station, media partners, actors and actresses, famous singers and also other related foundation, it becomes creative and innovative zakat mobilization. Certainly, auction action was main part of this event, for instance some singers auctioning her books to collect social fund and also by this program managed to raised funds in fantastic score 1.814.476.555 rupiahs.

Reflecting on the Success of Fundraising Auction of 'Islamic Relief Foundation' in 2017

In overseas, Islamic Relief Worldwide was established in 1984 by Dr Hany El-Banna and fellow students from the University of
Birmingham in the UK in response to the famine in Africa. Launching an appeal, they went door to door and from mosque to mosque asking for money, and this paid for food for people affected by the famine.

In 1985, Islamic Relief's began its first project - sponsoring a chicken farm in Sudan. That same year, its founders hired a small office in Mosely, in Birmingham, and from there raised $£ 100,000$ for the famine response. Islamic Relief grew at a rapid rate, and over the next five years, started working in Mozambique, Iran, Pakistan, Malawi, Iraq, and Afghanistan, among others, responding to emergencies and distributing clothes, food, offering health support and beginning the long-term project that is now our One-to-One Orphan Sponsorship programme.

Islamic Relief is a truly global organisation, working in more than 40 countries providing emergency aid, carrying out long-term development, and campaigning for change. Our international headquarters are based in Digbeth, in Birmingham, UK, but we have offices in countries including Bangladesh, USA, Germany, Iraq, Lebanon, Sweden, Australia, Malaysia, South Africa, and Mali (www.Islamic-relief.org, 2018).

Since 2003 Islamic Relief's charity week has raised more than $£ 6.7 \mathrm{~m}$ for 49 projects helping more than 140,000 orphans and needy children worldwide. On October $17^{\text {th }} 2017$, Islamic Relief did spectacular charity week and it raised fund about $£ 1,169,285.48$. It was used by Islamic Relief to provide aid and assistance to vulnerable children around the world. The provisional total beats by over $£ 100,000$ last year's thenrecord-breaking $£ 1,057,220.12$ (Madden, 2017).

The fundraising auctions proved particularly popular, with a banana selling for $£ 3,000$ at the UCL dinner and auction, making it possibly the world's mostexpensive fruit. Elsewhere, 18 brick-themed cakes were auctioned for a cumulative total 
of $£ 82,662$ and a canvas painting at the University of Exeter sold for $£ 2,500$. This was a fantastic achievement. Thousands of students and volunteers across the UK and around the world have given of their time and energy to fundraise for Charity Week, working so hard and so creatively to achieve so much for those children and young people who have so little (www.Islamic-relief.org, 2018).

On the other hands, Dhompet Dhuafa and other philanthropic organization could learn from glory of Islamic Relief as internationally role model of Islamic NGO. Beside could improve the professionalism of fundraising by tenders/auction with the tips follows 1) Get attractive items for your auction; 2) Create a buzz around the event; 3). Stagger the auction closing times; 4) Utilize mobile apps; 5) Have consolation prizes available; 6) Make it easy to bid; 7). Take it online; 8) Place signs strategically; 9) Rules and regulations; and 10) Thank your donors (Mostert, 2018). A silent auction is a popular, profitable fundraiser for nonprofit organization that big success in abroad but rarely in Indonesia.

\section{CONCLUSION}

The purpose of the study is to identify, to explore and to analyse the effectiveness of fundraising strategy by tendering/auctioning its programs to collect productive zakat in Dompet Dhuafa organization as success zakat fundriser. The result indicate significant benefit of implication of productive zakat both in BAZNAS and Dompet Dhuafa. Productive zakat plays the important role it is eradicating poverty and increasing prosperity index in 28 provinces in 2017 and also ensuring sustainable economic empowerement of the poor.

The results also demonstrated the strong influence strategy of productive zakat fundraising. In this case, Zakat collection by tender or auctioning program. This is Dompet Dhuafa's creative and extraordinary approaches which is not many philanthropic organization in Indonesia used it. It is kind of modern and innovative method of fundraising which need proffesional improvement for next bigger success. According to this, Islamic Relief Foundation UK, becomes great role model for developing fundraising strategy at international level.

\section{REFERENCES}

Ahmed, Habib (2004), The Role of Zakat and Awqf in Poverty Alleviation, Occational Paper No.8, Islamic Research and Training Institute (IRTI)-Islamic Development Bank (IDB), ISBN: 9960-32-150-9, downloaded on Monday August $27^{\text {th }}$, 2018.

Ali, Mohd; Asri Mohd, et al (2017), Factors That Influence The Zakat Collection Funds: A Case In Kuantan, South East Asia Journal of Contemporary Business, Economics and Law, Vol. 13, Issue 1(August), ISSN 22891560 .

Akmal, Izatul binti Ismail; Nasri, Muhammad bin Hussain, (2017), Productive Zakat Distribution by Zakat Institutions in Malaysia, International Journal of Academic Research in Business and Social Sciences 2017, Vol. 7, No. 3 ISSN: 2222-6990, 554 www.hrmars.com, DOI: $10.6007 /$ IJARBSS/v7-i3/2758 URL:

http://dx.doi.org/10.6007/IJARBSS/v 7-i3/2758.

Anis, Fahami M; Kassim, Salina Kassim (2016), Effectiveness of Zakat-Based Programs on Poverty Alleviation and Economic Empowerment of Poor Women: A Case Study of Bangladesh, 
Journal of Islamic Monetary Economics and Finance, Vol. 1, No.2, February 2016, https://www.researchgate.net/publica tion/296699929

Anwar (2017), The Law Of Productive Zakat In Islam And Its Impact Towards Economy, International Journal of Engineering Technologies and Management Research_IJTMR, Vol. 4, No. 2(2017), 10-21. DOI: 10.5281 /zenodo. 293800

Bashori, M. Anwar (2018), Mendorong Pengembangan Islamic Social Finance dalam Rangka Mewujudkan Masyarakat Sejahtera, DEKS BI, https://www.bi.go.id/id/publikasi/seri -ekonomi-keuangansyariah/Pages/MendorongPengembangan-Islamic-SocialFinance-dalam-RangkaMewujudkan-Masyarakat-SejahteraFESYAR-250817.aspx, downloaded on Monday August $27^{\text {th }}, 2018$.

Beik, Irfan Sauki, (2017), Indonesia Zakat Outlook 2017, Pusat Kajian dan Strategik (Puskas) Badan Amil Zakat Nasional (BAZNAS). www.pusat. BAZNAS.go.id

Beik, Irfan Sauki, (2009), Analisis Peran Zakat dalam Mengurangi Kemiskinan - Studi Kasus Dompet Dhuafa Republika, Zakat \& Empowering: 2:47-55_Jurnal Pemikiran dan Gagasan - Vol II 2009.

Carpenter, Jeffrey et al (2007), Charity Auctions: A Field Experiment, The Economic Journal, forthcoming, February 5 , 2007,http:/community.middlebury.e $\mathrm{du} / \sim$ jcarpent/EC499/Carpenter $\% 20 \mathrm{H}$ olmes $\% 20$ and $\% 20$ Matthews $\% 20200$ $7 \% 20 \mathrm{EJ} . \mathrm{pdf}$

Carter, Terrance S. (2012), The New CRA Fundraising Guidance - What Practitioners and Boards Need to
Know, http://sectorsource.ca/sites/default/fil es/cra fundraising guidance webina r_02142012_0.pdf

Dompet Dhuafa document in Ramon Magsaysay Award Foundation (2016), "Wallet of The Poor": AModel Of Sustainable Faith-Based Giving, https://www.scribd.com/document/3 24194813/Wallet-of-The-Poor-AModel-of-Sustainable-Faith-BasedGiving, downloaded on Tuesday September $4^{\text {th }}, 2018$.

Gasca, Peter (2015), 7 Essential Tips for an Effective Fundraising Strategy, Fundraising

https://www.entrepreneur.com/article /244966, downloaded on Tuesday September $4^{\text {th }}, 2018$.

Holloway, R (2001), Toward Financial SelfReliance, London; Aga Khan Foundation in Sulthoni et al. (2018), Waqf Fundraising Management: A Proposal for A Sustainable Finance of the Waqf Institutions, Journal of Islamic Monetary Economic and Finance, Vol. 3, Special Issue (2018), pp. 201-234. P-ISSN: 2460-6146, eISSN: 2460-6618.

Lessy, Zulkipli (2013), Philanthropic Zakat for Empowering Indonesia's Poor: A Qualitative Study of Recipient Experiences at Rumah Zakat, Doctoral Philosophy in the School of Social Work, Indiana University, https://core.ac.uk/download/pdf/4695 7789.pdf, downloaded on Monday September $3^{\text {th }}, 2018$

Madden, Imran (2017), Thanks a million as Charity Week young people raise record sum for Islamic Relief children's projects, https://www.islamicrelief.org.uk/thanks-million-charityweek-young-people-raise-recordsum-islamic-relief-childrens- 
projects/, downloaded on Monday August 27 $7^{\text {th }}, 2018$.

Mostert, Cari (2018), 10 Tips to Make Your Silent Auction a Success!, Fundraising Events Read more at http://www.fundraisingip.com/fundra ising/tips-silent-auctionsuccess/\#Ky8zb9OOhPzQB6Vb.99

Nasar, Fuad M. in Abudullah, Nurudin (2018), Zakat Nasional 2017 Tumbuh 20\% Jadi $R p \quad 6 \quad$ Triliun, http://kabar24.bisnis.com/read/20180 102/15/722684/Zakat-nasional-2017tumbuh-20-jadi-rp6-triliun, downloaded on Monday September $3^{\text {th }}, 2018$.

Ridwan, Muhammad (2005), Manajemen Baitul Maal Wa Tamwil (BMT), cet 2. Yogyakarta: UII Press

Rusydiana, Aam (2016), Manakah Lembaga Zakat Paling Populer?, http://izzatinstitute.blogspot.com/2016/06/mana kah-lembaga-Zakat-palingpopuler.html, SMART Consulting, downloaded on Monday August 27 , 2018

Scapens, R. W. (1990), Researching management accounting practice: The role of case study methods, British accounting review, 22(3), pp. 259281.

Shank, G.D. (2002), Qualitative research, A personal skill approach, Upper Saddle River: Merrill-Prentice Hall.
Sudirman (2016), Implementing "Zakat”Based Microfinance in Indonesia, IOSR Journal of Economics and Finance (IOSR-JEF) e-ISSN: 2321 5933, p-ISSN: 2321-5925.Volume 7, Issue 5 Ver. II (Sep. - Oct. 2016), PP 57-61 www.iosrjournals.org DOI: 10.9790/5933-0705025761 www.iosrjournals.org 57 | Page.

Taufan, YN (2017), Laporan Kinerja Dompet Dhuafa 2016, https://www.dompetdhuafa.org/post/ detail/7947/laporan-kinerja-dompetdhuafa-periode-2016, downloaded on Monday September $3^{\text {th }}, 2018$.

Uyang (2015), Voice of Children : Perolehan Sementara, Lebih Dari Semilyar Donasi Penggalangan Dana Terkumpul, https://www.dompetdhuafa.org/post/ detail/1468/voice-of-childrenperolehan-sementara---lebih-darisemilyar-donasi-penggalangan-danaterkumpul-downloaded on Monday August $27^{\text {th }}, 2018$.

http://www.dompetdhuafa.org

https://angin.id/2018/03/23/reita-annur

Sulistyowati

STIE Indonesia Banking School Indonesia 